\title{
Quality of jackfruit seedlings under saline water stress and nitrogen fertilisation
}

\section{Qualidade das mudas de jaqueira sob estresse salino da água e adubação nitrogenada}

\author{
Francisco Ítalo Fernandes de Oliveira ${ }^{1}$; Antônio Gustavo de Luna Souto ${ }^{2 *}$; \\ Lourival Ferreira Cavalcante ${ }^{3}$; Wiliana Júlia Ferreira de Medeiros ${ }^{1}$; \\ Francisco Thiago Coelho Bezerra ${ }^{4}$; Marlene Alexandrina Ferreira Bezerra ${ }^{2}$
}

\begin{abstract}
The lack of good quality water for agriculture purposes regarding salts and quantity in relation to demand for the plants has, for more than 30 years, been forcing the use of restrictive water because of salinity issues in agricultural production systems worldwide. In Brazil, the situation is no different, in the semi-arid areas, there are reports of losses of seed germination, initial growth of seedlings and yield of crops of commercial importance due to the salinity of the water used in irrigation systems. Therefore, an experiment was carried out from June to September/2014 in a protected environment, with a plastic film on the upper base and a thin screen against insects on the sides, to evaluate the effects of salinity interaction between water irrigation and nitrogen fertilisation sources on soil salinity, initial plant growth and the quality of the jackfruit seedlings. The treatments were distributed in randomised blocks, in the factorial scheme $5 \times 3$, reference irrigation water of $0.3,1.0,2.0,3.0$ and $4.0 \mathrm{dS} \mathrm{m}^{-1}$, in soil with and without ammonium sulfate and urea. An increase in the salinity of the irrigation water to 1.32 and $1.70 \mathrm{dS} \mathrm{m}^{-1}$ on the substrate without nitrogen stimulated an increase in the number of leaves and leaf area of the jackfruit seedlings. The ammonium sulfate was the nitrogen source that mainly contributed to the increase of soil salinity and to the reduction of the quality index of the seedlings. Despite the reduction of the Dickson quality index due to the salinity of the irrigation water and the nitrogen sources, the seedlings were suitable for cultivation.
\end{abstract}

Key words: Artocarpus heterophyllus, water salinity, nitrogen fertilisers.

\section{Resumo}

A falta de água de boa qualidade para fins agrícola em relação aos sais e quantidade em relação à demanda pelas plantas tem, há mais de 30 anos, forçado o uso de água restritiva por problemas de salinidade em sistemas de produção agrícola em todo o mundo. No Brasil, a situação não é diferente; nas áreas semiáridas, há relatos de perdas de germinação de sementes, crescimento inicial de mudas e rendimento de culturas de importância comercial devido à salinidade da água utilizada em sistemas de irrigação. Assim, foi realizado um experimento de junho a setembro de 2014 em ambiente protegido, com

\footnotetext{
1 Mestres em Ciência do Solo, Universidade Federal do Ceará, UFC, Fortaleza, CE, Brasil. E-mail: italooliveiraufpb@gmail.com; juliamedeirosagro@gmail.com

2 Mestres em Ciência do Solo, Universidade Federal da Paraíba, UFPB, Areia, PB, Brasil. E-mail: gusluso@hotmail.com; marlene_agro@hotmail.com

3 Pesquisador, Instituto Nacional de Ciência e Tecnologia em Salinidade, INCTSal, Prof., Programa de Pós-Graduação em Agronomia, UFPB, Areia, PB, Brasil. E-mail: lofeca@cca.ufpb.br

4 Dr. em Agronomia, UFPB, Areia, PB, Brasil. E-mail: bezerra_ftc@yahoo.com.br

* Author for correspondence
}

Received: Aug. 24, 2016 Approved: May 15, 2017 
filme plástico na base superior e tela fina nas laterais contra insetos, para avaliar os efeitos da interação salinidade entre irrigação e fontes de fertilização nitrogenada na salinidade do solo, crescimento inicial da planta e qualidade das mudas de jaqueira. Os tratamentos foram distribuídos em blocos casualizados, no esquema fatorial $5 \times 3$, referente às água de irrigação de 0,$3 ; 1,0 ; 2,0 ; 3,0$ e $4,0 \mathrm{dS} \mathrm{m}$ m $^{-1}$, em solo com e sem sulfato de amônio e ureia. $\mathrm{O}$ aumento na salinidade da água de irrigação para 1,32 e $1,70 \mathrm{dS} \mathrm{m}^{-1}$ no substrato sem nitrogênio estimulou aumento no número de folhas e área foliar das plântulas de jaqueira. O sulfato de amônio foi à fonte de nitrogênio que mais contribuiu para o aumento da salinidade do solo e para a redução do índice de qualidade das mudas. Apesar da redução do índice de qualidade de Dickson devido à salinidade da água de irrigação e das fontes de nitrogênio, as mudas estavam adequadas para o plantio.

Palavras-chave: Artocarpus heterophyllus, salinidade da água, fertilizante nitrogenado.

\section{Introduction}

Currently, irrigated agriculture is facing serious problems worldwide due to the scarcity of adequate water resources, especially in arid and semi-arid regions (ASSOULINE et al., 2015). The chemical quality, often with a high presence of soluble salts, forces many farmers to use water of restricted use for agricultural crops (DIAS; BLANCO, 2010; SHAHID; RAHMAN, 2011). The use of low quality water combined with the application of excessive amounts of chemical fertilisers has been one of the causes that aggravate the problem of salinization of agricultural soils (HAN et al., 2015).

The use of saline water from the salt threshold level supported by plants, both food and non-food, compromises the productive capacity of crops and constitutes a serious problem to the production system, by changing the physical and chemical soil attributes by specific ions on the metabolic and physiological, nutritional, growth and production processes of the plants (ARAGÃO et al., 2010; ZHANG et al., 2013; TAÏBI et al., 2016). However, according to Cavalcante et al. (2010), due to the scarcity of water resources in the northeastern semiarid region, the water use is the only option for farmers to provide water to continue their primary activity for income.

One of the ways of to use high saline water in agriculture is by the production of seedlings either for the initial growth of food crops, non-food crops or seedlings for reforestation purposes - as done by
Cavalcante et al. (2010) for guava seedlings (Psidium guajava), Nobre et al. (2014) in the initial growth of castor bean (Ricinus communis L.) destined for the production of biodiesel, and Mesquita et al. (2015) in young neem plants (Azadirachta indica L.) for reforestation means of degraded areas by salts.

Among the existing fruit trees in the northeast, the jackfruit (Artocarpus heterophyllus Lam.), which is disseminated by seeds and could be propagated by using saline water, is an alternative, and more information is needed on the behaviour of this species with saline environments. The jackfruit belongs to the family Moraceae - originally from India was introduced in Brazil in the $17^{\text {th }}$ century and is cultivated in an extractive way in domestic orchards in almost all of Brazil (LORENZI et al., 2006). Thus, agronomic knowledge about the propagation and formation of seedlings can encourage the small producers to explore the fruits for in natura consumption or processing in a commercial way (ASQUIERI et al., 2008; MORAIS et al., 2012).

Among the alternatives for cultivation in saline environments, nitrogen fertilisation has contributed to minimise the effects of salts on plants, in addition to promoting plant growth. Nitrogen $(\mathrm{N})$ is a constituent nutrient of several cellular molecules, such as chlorophyll, nucleic acids, proteins, enzymes and amino acids (TAIZ et al., 2017); it can reduce the effect of salinity on plants by participating in osmoregulatory molecules present in the root region (NADIAN et al., 2012). However, 
due to the nitrogen sources being commercialised in the form of salts, according to the potential of the mineral input in reducing the osmotic pressure of the soil solution in comparison to the sodium nitrate, which is the standard fertiliser for salinity studies (SILVA; BORGES, 2009). The fertiliser, instead of mitigating, may increase the soil saline concentration, especially when applied together with irrigation water (CHEN et al., 2010), causing morphophysiological and yield losses, mainly for salt sensitive plants.

There are few studies about the interaction of salinity $\times$ nitrogen in different agricultural crops, mostly with divergent results regarding the mitigation of nitrogen fertilisation of the salts on plants (OLIVEIRA et al., 2014). For sugarcane (Saccharum sp.), Nadian et al. (2012) verified that the application of $\mathrm{N}$ promoted higher growth and production of plants under saline stress. Differently, Nobre et al. (2010) and Oliveira et al. (2010), studying the effect of nitrogen on sunflower (Helianthus anus) irrigated with saline water, did not obtain results for the traits of growth and production. Thus, the importance of this work in elucidating the role of $\mathrm{N}$ in reducing the deleterious effects of salinity on the initial growth of jackfruit seedlings is justified, since these responses are variants among species.

The aim of this work was to evaluate the effects of saline irrigation water on soil with and without nitrogen sources on the soil salinization process, initial growth and quality of jackfruit seedlings.

\section{Material and Methods}

This experiment was carried out from June to September of 2014 in a protected environment of the Universidade Federal da Paraíba, in the city of Areia-PB, located in the Microregion of the Brejo Paraibano, Paraiba State, Brazil, located in the geographical coordinates: latitude $6^{\circ} 58^{\prime} 12^{\prime} \mathrm{S}$, longitude $35^{\circ} 42^{\prime} 15^{\prime \prime} \mathrm{W}$ of the Greenwich Meridian and altitude of $619 \mathrm{~m}$.

The climate of the municipality is type As', hot and humid, with temperature and relative humidity of $25{ }^{\circ} \mathrm{C}$ and $75 \%$ in the warmer months, and 21.6 ${ }^{\circ} \mathrm{C}$ and $87 \%$ in the colder months. The average precipitation in the region is $1,200 \mathrm{~mm}$ per year, with rainfall concentrated in the periods of March through August. Mean data for temperature and air humidity in the environment were recorded daily (Figure 1) during the experimental period with the device DataLogger ${ }^{\circledR}$ (model HT-500).

Figure 1. Daily mean values of temperature and relative humidity in the greenhouse of the Departament of Soil and Rural Engineering, UFPB, Areia, Paraíba.

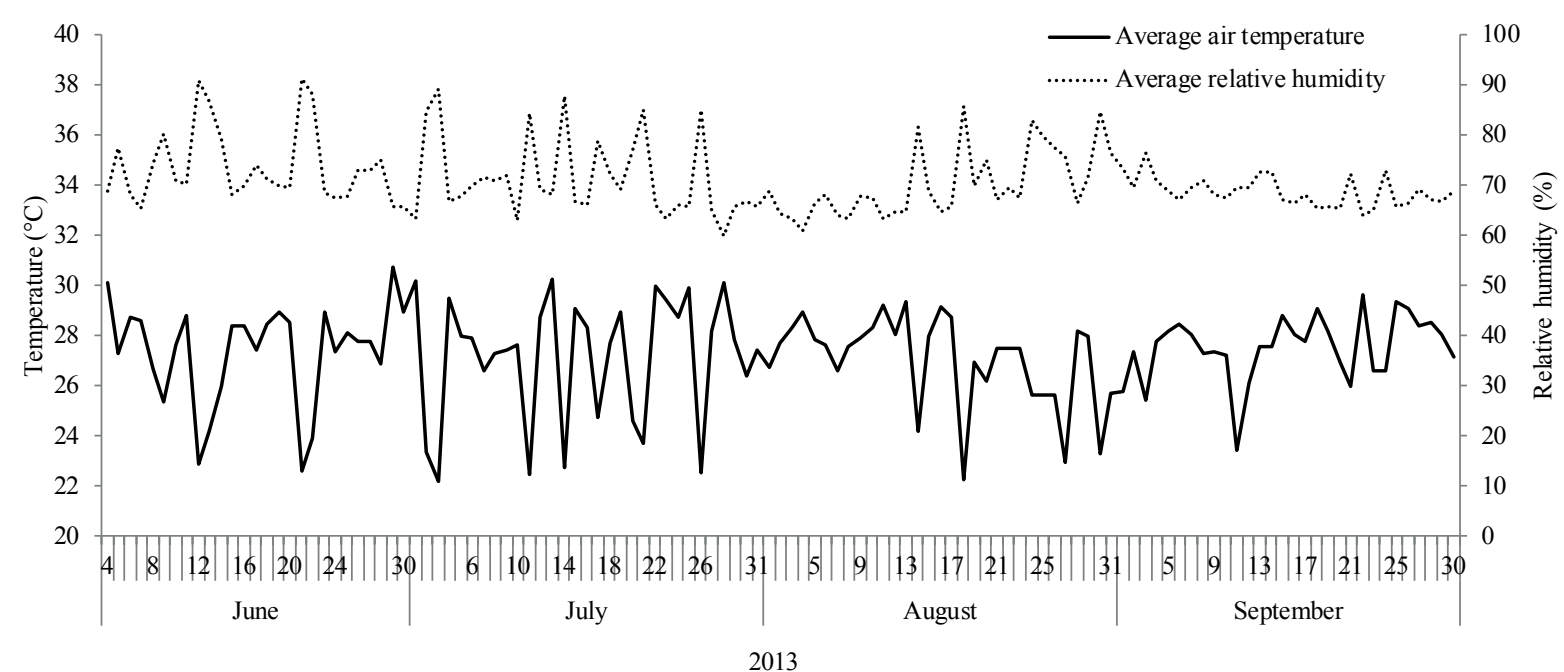


The substrate had $1.3 \mathrm{dm}^{-3}$ of an Oxisoil classified as Red-Yellow Latosoil placed in PET bottles with $35 \mathrm{~cm}$ of height, with a sandy-loamy clay texture collected in the $0-20 \mathrm{~cm}$ layer, with the chemical attributes for the salinity (RICHARDS, 1954), fertility and physics according to Embrapa (2011) (Table 1).

Table 1. Chemical properties of fertility, salinity and physical of the soil used as substrate.

\begin{tabular}{lclc}
\hline \multicolumn{1}{c}{ Chemical Attributes } & Value & \multicolumn{1}{c}{ Physical Attributes } & Value \\
\hline $\mathrm{pH}$ in water $(1.0: 2.5)$ & 4.90 & Sand $\left(\mathrm{g} \mathrm{kg}^{-1}\right)$ & 552 \\
$\mathrm{EC}_{\mathrm{se}}\left(\mathrm{dS} \mathrm{m}^{-1}\right)$ & 0.17 & Silt $\left(\mathrm{g} \mathrm{kg}^{-1}\right)$ & 101 \\
$\mathrm{OM}\left(\mathrm{g} \mathrm{kg}^{-1}\right)$ & 17.00 & Clay $\left(\mathrm{g} \mathrm{kg}^{-1}\right)$ & 347 \\
$\mathrm{P}\left(\mathrm{mg} \mathrm{dm}^{-3}\right)$ & 13.50 & $\mathrm{SD}\left(\mathrm{kg} \mathrm{dm}^{-3}\right)$ & 1.11 \\
$\mathrm{~K}^{+}\left(\mathrm{cmol}_{\mathrm{c}} \mathrm{kg}^{-1}\right)$ & 0.12 & $\mathrm{PD}\left(\mathrm{g} \mathrm{cm}^{-3}\right)$ & 2.67 \\
$\mathrm{Ca}^{2+}\left(\mathrm{cmol}_{\mathrm{c}} \mathrm{kg}^{-1}\right)$ & 1.58 & $\mathrm{TP}\left(\mathrm{m}^{3} \mathrm{~m}^{-3}\right)$ & 0.59 \\
$\mathrm{Mg}^{2+}\left(\mathrm{cmol}_{\mathrm{c}} \mathrm{kg}^{-1}\right)$ & 0.52 & Humidity $(0.33 \mathrm{MPa})$ & 23.00 \\
$\mathrm{Na}^{+}\left(\mathrm{cmol}_{\mathrm{c}} \mathrm{kg}^{-1}\right)$ & 0.09 & Humidity $(15 \mathrm{MPa})$ & 14.65 \\
$\mathrm{Al}^{3+}\left(\mathrm{cmol}_{\mathrm{c}} \mathrm{kg}^{-1}\right)$ & 0.80 & Textural Class & Frank Clay Sandy \\
$\mathrm{H}^{+}+\mathrm{Al}^{3+}\left(\mathrm{cmol}_{\mathrm{c}} \mathrm{kg}^{-1}\right)$ & 4.83 & & \\
$\mathrm{SEB}\left(\mathrm{cmol}_{\mathrm{c}} \mathrm{gk}^{-1}\right)$ & 2.31 & & \\
$\mathrm{CEC}\left(\mathrm{cmol}_{\mathrm{c}} \mathrm{gk}^{-1}\right)$ & 7.14 & & \\
$\mathrm{ESP}(\%)$ & 1.26 & & \\
\hline
\end{tabular}

$\mathrm{ECse}=$ electric conductivity of the saturation extract; OM. = organic matter; $\mathrm{SEB}=$ sum of exchangeable bases; CEC = cation exchange capacity; $\mathrm{ESP}=$ exchangeable sodium percentage; $\mathrm{SD}=$ soil density; $\mathrm{PD}=$ particle density; $\mathrm{TP}=$ total porosity.

The treatments were distributed in randomised blocks with three replicates and three units per treatment, arranged in the factorial scheme $5 \times$ 3 , referring to levels of electrical conductivity of irrigation water (ECiw) of 0.3, 1.0, 2.0, 3.0 and 4.0 $\mathrm{dS} \mathrm{m}^{-1}$ in the soil without nitrogen, with ammonium sulphate and urea, totalling 45 experimental plots and 135 plants for evaluation.

The electrical conductivity levels of the irrigation water were obtained by dissolving in nonsaline water $\left(\mathrm{ECiw}=0.3 \mathrm{dS} \mathrm{m}^{-1}\right)$ of sodium chloride $(\mathrm{NaCl})$, calcium chloride $\left(\mathrm{CaCl}_{2} \cdot 2 \mathrm{H}_{2} \mathrm{O}\right)$, magnesium chloride $\left(\mathrm{MgCl}_{2} \cdot 6 \mathrm{H}_{2} \mathrm{O}\right)$ and potassium chloride $(\mathrm{KCl})$ in proportions of 6: 2: 1: 1, with 95 and $98 \%$ purity for sodium chloride and the other salt sources. For the substrate preparation were incorporated, 150 and $300 \mathrm{mg} \mathrm{kg}^{-1}$, respectively, of $\mathrm{K}$ and $\mathrm{P}$ (NOVAIS et al., 1991) from potassium chloride $\left(60 \% \mathrm{~K}_{2} \mathrm{O}\right)$ and single superphosphate $\left(21 \% \mathrm{P}_{2} \mathrm{O}_{5} ; 18 \% \mathrm{Ca}^{2+}\right.$ and $12 \% \mathrm{~S}$ ). The nitrogen fertilisation was based on the absence and application of $150 \mathrm{mg} \mathrm{dm}^{-3}$ of $\mathrm{N}$ (NOVAIS et al., 1991) in the substrate as ammonium sulphate $(21 \%$ of $\mathrm{N}$ and $23 \%$ of $\mathrm{S})$ and urea ( $45 \%$ $\mathrm{N})$, divided into two equal applications on days 60 and 75 after sowing (DAS).

The jackfruit seeds of the soft variety were obtained from selected fruits based on size, complete maturation and fruit mass from plants located in the Areia city, Paraiba State, Brazil.

One seed was sown in each container. The first counting of normal seedlings occurred 18 days after 
sowing (DAS) and the process stabilised at 31 DAS. The irrigations with each type of water were made daily by the weighing process and watering at every $24 \mathrm{~h}$ the volume of water evaporated on the previous day in order to keep the substrate with moisture as close as possible to the level of pot capacity.

At 85 DAS, the growth was evaluated by measuring the height of the plant with a graduated ruler from the soil to the last definitive pair of leaves; the stem diameter on the surface of the soil was measured using a Digimess ${ }^{\circledR}$ digital caliper; and the leaves were counted. After this, all leaves were collected from each experimental unit and an individual leaf area reading was performed for the quantification of the leaf area of the plants of each treatment using LAI-model 2200 equipment. From the leaf area and leaf matter, the specific leaf area (ELA) $[E L A=($ leaf area / leaf matter) $]$ was calculated according to the methodology suggested by Benincasa (2003).

The Dickson quality index (DQI) was obtained based on biometric growth and the dry matter of total plant shoots and roots, according to Dickson et al. (1960):

$\underset{\text { DQI }}{\text { (Eq. } 1)}=\mathrm{TDM} /[(\mathrm{H} / \mathrm{SD})+(\mathrm{DMS} / \mathrm{DMR})]$

Where:

DQI $=$ Dickson quality index

$\mathrm{TDM}=$ Total dry matter $(\mathrm{g})$

$\mathrm{H}=$ Plant height $(\mathrm{cm})$

$\mathrm{SD}=$ Stem diameter $(\mathrm{mm})$

DMS $=$ Dry matter of shoot $(\mathrm{g})$

$\mathrm{DMR}=$ Dry matter of roots $(\mathrm{g})$
Simultaneously to plant evaluations, soil samples were collected on the surface, middle and finish of the substrate of each treatment to determine the electrical conductivity of the saturation extract (ECse).

The data collected were submitted to analysis of variance for the diagnosis of significant effects of the factors and their interactions by the F test ( $\mathrm{p} \leq$ 0.05 and $p \leq 0.01$ ). The mean values for the soil with and without the nitrogen fertilisations were compared by the Tukey test $(\mathrm{p} \leq 0.05)$, and those related to the electrical conductivity of the irrigation water, by regression study using $\mathrm{SAS} \circledast$ software, version 9.2. (SAS, 2008).

\section{Results and Discussion}

The water salinity levels $\times \mathrm{N}$ sources' interaction had a significant effect on plant height, leaf emission, leaf area and specific leaf area and on the Dickson quality index of the seedlings (DQI) (Table 2). The stem diameter was influenced by the water salinity; the electrical conductivity of the soil saturation extract responded to the isolated effects of fertilisation with the nitrogen sources and the salinity of the irrigation water. This corroborates with Nadian et al. (2012) who found significant effects of the interaction of water salinity $\times$ nitrogen on the parameters of growth and production of sugarcane, but diverges from Nobre et al. (2010) and Oliveira et al. (2010), who concluded that the interaction water salinity $\times$ nitrogen fertilisation did not interfere with the growth and production of sunflowers. 
Table 2. Summary of the analysis of variance, by the mean square, of the effect of nitrogen sources $(\mathrm{N})$ and irrigation water salinity levels (A) on the formation of jackfruit seedlings.

\begin{tabular}{ccccccccc}
\hline \multirow{2}{*}{ SV } & \multirow{2}{*}{ FD } & \multicolumn{7}{c}{ Mean Square } \\
\cline { 3 - 8 } & & ECse & HP & SD & NL & LA & SLA & DQI \\
\hline Blokcs & 3 & $1.60^{\text {ns }}$ & $26.24^{* *}$ & $0.65^{* *}$ & $0.62^{\text {ns }}$ & $887.60^{\text {ns }}$ & $1038.67^{\text {ns }}$ & $0.02^{* *}$ \\
Water (A) & 4 & $240.45^{* *}$ & $118.02^{* *}$ & $2.82^{* *}$ & $0.55^{\text {ns }}$ & $24438.63^{* *}$ & $3295.57^{\text {ns }}$ & $0.16^{* *}$ \\
Nitro (N) & 2 & $35.00^{* *}$ & $0.97^{\text {ns }}$ & $0.04^{\text {ns }}$ & $0.60^{\text {ns }}$ & $1570.21^{\text {ns }}$ & $4121.31^{\text {ns }}$ & $0.02^{* *}$ \\
A $\times$ N & 8 & $3.10^{\text {ns }}$ & $28.88^{* *}$ & $80.26^{\text {ns }}$ & $0.68^{*}$ & $4048.04^{* *}$ & $3730.98^{*}$ & $0.01^{* *}$ \\
Residue & 42 & 1.82 & 3.33 & 0.12 & 0.31 & 875.23 & 1481.95 & 0.003 \\
\hline CV $(\%)$ & & 15.55 & 9.59 & 6.68 & 11.83 & 14.76 & 23.22 & 11.53 \\
\hline
\end{tabular}

$\mathrm{SV}=$ source of variation; freedom degree; ${ }^{\text {ns }}=$ not significant $; *=$ significant at $5 \%$ probability; $* *=$ significant at $1 \%$ probability.

The increase in the saline concentration of the irrigation water and the different nitrogen sources significantly increased the initial non-saline soil character, with $\mathrm{ECse}=0.17 \mathrm{dSm}^{-1}$ (Table 1), to strongly saline (Figure 2). The average electric conductivity of the soil saturation extract was linearly elevated, at $2.98 \mathrm{dS} \mathrm{m}^{-1}$, per unit increase of saline irrigation water levels (Figure 2A). The values were increased from 3.43 to $14.47 \mathrm{dS} \mathrm{m}^{-1}$, between treatments irrigated with water of lower $\left(0.3 \mathrm{dS} \mathrm{m}^{-1}\right)$ and higher salt content $\left(4.0 \mathrm{dS} \mathrm{m}^{-1}\right)$. A similar situation was reported by Garcia et al. (2008), who found that the salinity of two soils (Fluovian Neosoil and Red Latosoil) were linearly elevated with an increase in the irrigation water salinity from the value of 8.87 to $11.51 \mathrm{dS} \mathrm{m}^{-1}$ when irrigated for 25 days, with water of $10 \mathrm{dS} \mathrm{m}^{-1}$.
Ammonium sulphate was the nitrogen source that mainly contributed to the increase in soil salinity (10.19 $\left.\mathrm{dS} \mathrm{m}^{-1}\right)$ compared to the non-fertilised treatment $\left(7.69 \mathrm{dS} \mathrm{m}^{-1}\right)$ and the one fertilised with urea $\left(8.17 \mathrm{dS} \mathrm{m}^{-1}\right)$; the treatments with non-urea and urea-fertilised did not differ statistically from each other (Figure 2B). According to Han et al. (2015), excessive nitrogen fertilisation can lead to the chemical degradation of the soil, contributing to the increase of salinization and acidification, mainly by the addition of $\mathrm{SO}_{4}^{2-}$ ions contained in ammonium sulphate. The electrical conductivity values of the soil saturation extract at the levels presented in Figure 2 compromise the plant growth in general (CAVALCANTE et al., 2010; DIAS; BLANCO, 2010; SHAHID; RAHMAN, 2011). 
Figure 2. Electrical conductivity of soil saturation extract, as a function of the electric conductivity of irrigation water.
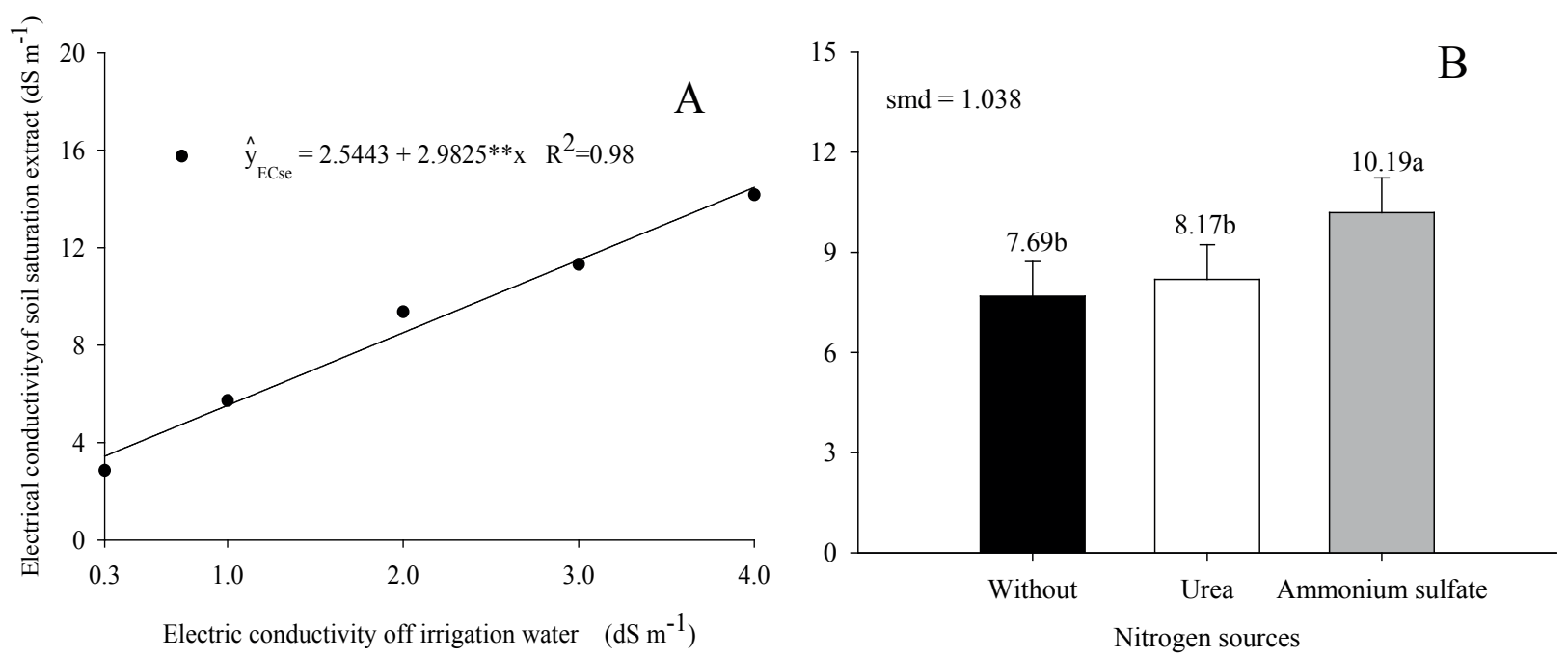

(A), in soil without nitrogen (•), with urea (口) and ammonium sulfate (匹) (B).

The height growth of the jackfruit seedlings was linearly inhibited in the treatments without $\mathrm{N}$, with urea and ammonium sulphate, respectively, at the levels of $1.906,2.152$ and $3.041 \mathrm{~cm}$ per unit increment of the electrical conductivity of the irrigation water (Figure 3). The values decreased from 22.26 to $15.21 \mathrm{~cm}, 23.07$ to 15.11 , and of 24.32 to $13.19 \mathrm{~cm}$ between plants irrigated with water of 0.3 and $4.0 \mathrm{dS} \mathrm{m}^{-1}$, respectively, in the soil without nitrogen, with urea and ammonium sulphate.

Figure 3. Height of jackfruit seedlings, as a function of the electric conductivity of irrigation water on the soil without nitrogen (-), with ammonium sulfate (- - ) and urea $(\cdots)$.

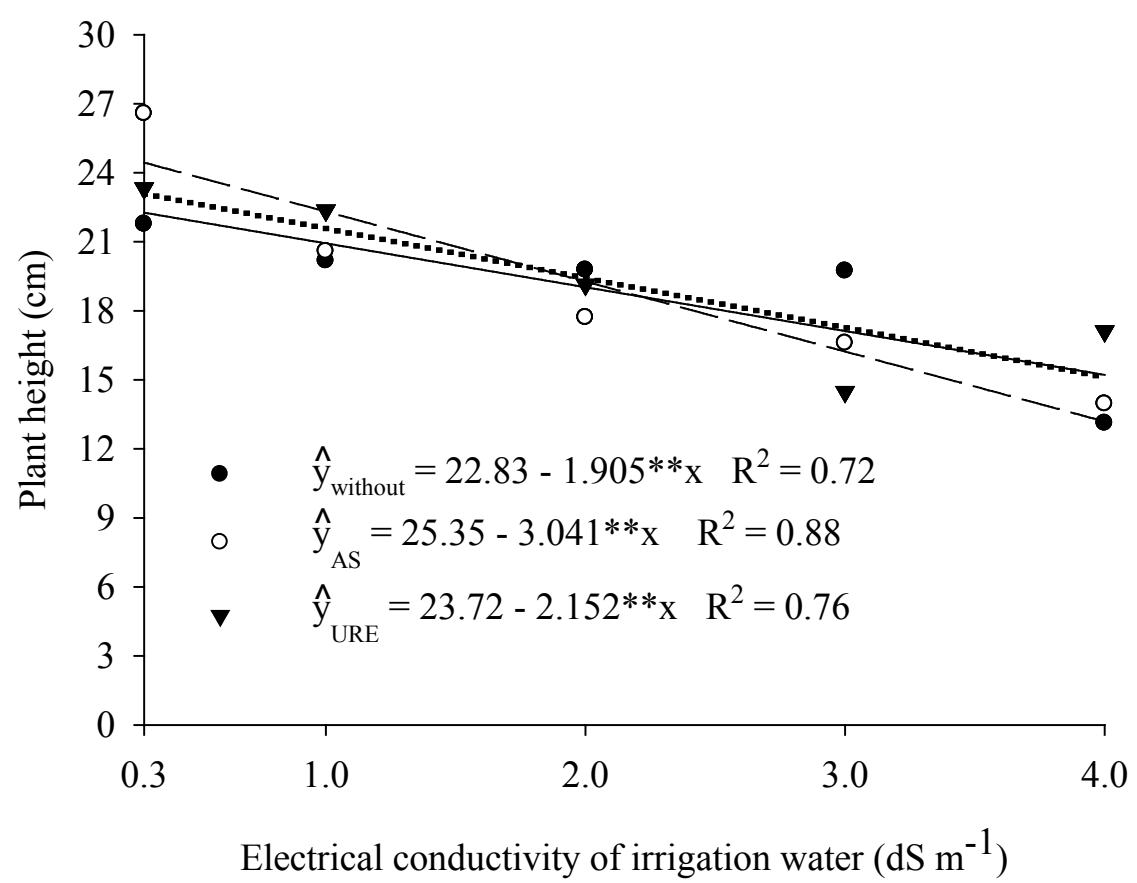


By data correlation analysis of the irrigated plants with water of higher and lower saline concentrations, losses of $31.67,34.51$ and $45.76 \%$ were found in the soil without nitrogen, with urea and ammonium sulphate, respectively. The higher severity of the ammonium sulphate, despite a lower salt content than urea, is due to its lower $\mathrm{N}$ content than urea, which promotes the osmotic pressure reduction of the soil solution compared to sodium nitrate, which is the standard salt for studies of the salinity of fertilisers to plants (SILVA; BORGES, 2009). The analysed data is in agreement with Alves et al. (2012), who found a reduction of $38.76 \%$ in the height of castor bean irrigated with saline water ranging from 0.6 to $4.6 \mathrm{dS} \mathrm{m}^{-1}$, as well as that observed by Oliveira et al. (2010) who evaluated the initial growth of sunflower under irrigation with saline water of 0.5 to $4.5 \mathrm{dS} \mathrm{m}^{-1}$ and nitrogen fertilisation; they found a greater loss of $36.0 \%$ caused by ammonium sulphate compared to $32.86 \%$ of loss related to urea.

In saline environments, most food and non- food crops undergo a biometric reduction in response to increased soil salt concentrations, by the toxicity of specific ions, reduction of osmotic potential of the soil solution and physiological and biochemical disturbances caused by saline stress in the root growth zone and in the interior of the plants (AMIRA; QADOS, 2011; AHMED et al., 2012).

The stem diameter of the jackfruit seedlings was inhibited by an increase in the electrical conductivity of the irrigation water (Figure 4). Did they all decrease from 5.68 to $5.62 ; 5.40 ; 5.03$ and $4.52 \mathrm{~mm}$ resulting in losses of 1.06, 4.92, 11.44 and $20.42 \%$, respectively, between the plants irrigated with water of $1.0 ; 2.0 ; 3.0$ and $4.0 \mathrm{dS} \mathrm{m}^{-1}$ compared to those irrigated with lower levels of saline water. Comparatively, the effects of saline stress on the diameter of the jackfruit stem exerted similar effects, as recorded by Cavalcante et al. (2010) in seedlings of guava cv. Paluma, where an increase in the salinity of irrigation water from 0.5 to $4.0 \mathrm{dS} \mathrm{m}^{-1}$ caused a reduction of $26.85 \%$ in the stem diameter of the plants.

Figure 4. Stem diameter on jackfruit seedlings, as a function of the electric conductivity on the irrigation water.

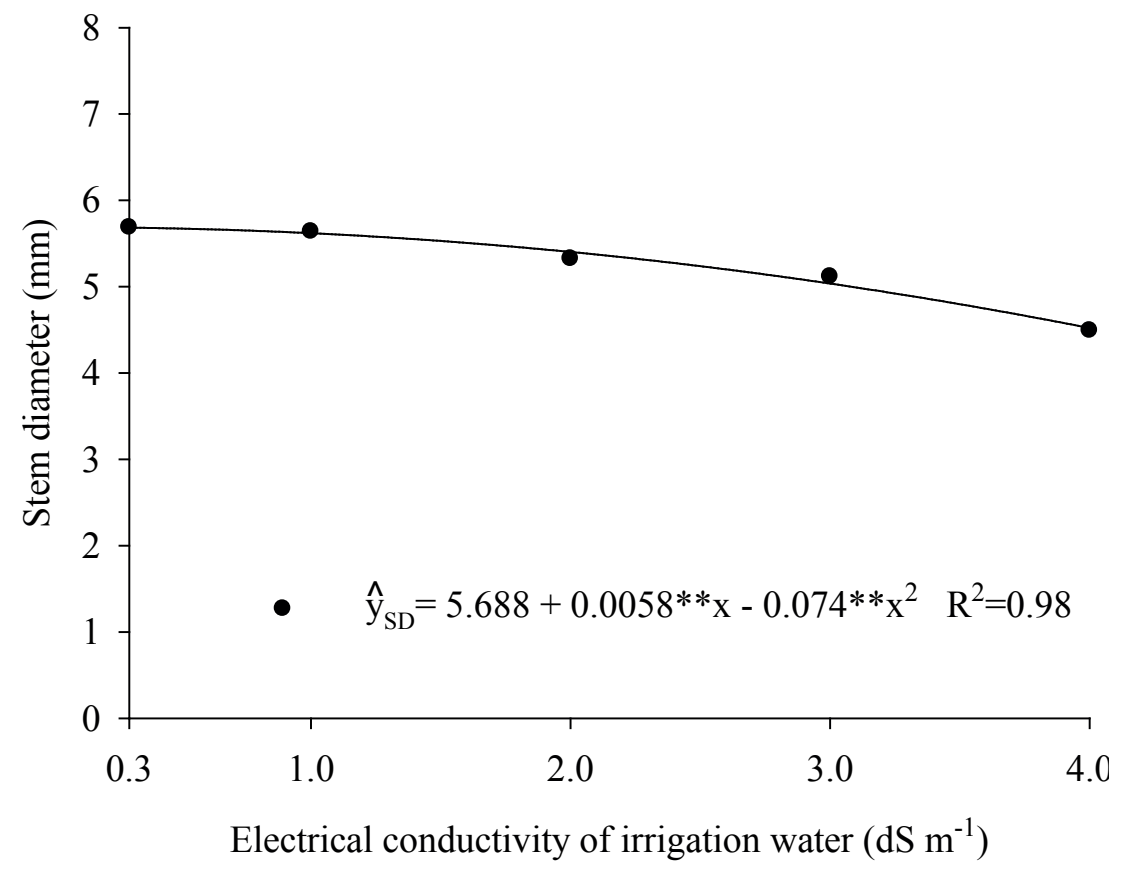


The inhibition of plant growth under saline stress is due to the degenerative effects of the saline mixture between cations, mainly $\mathrm{Ca}^{2+}, \mathrm{Mg}^{2+}, \mathrm{Na}^{+}, \mathrm{NH}_{4+}$ and anions such as $\mathrm{Cl}^{-}, \mathrm{CO}_{3}^{2-}, \mathrm{HCO}_{3-}, \mathrm{SO}_{4}^{2-}, \mathrm{NO}_{3}^{-}$and the specific action of ions such as $\mathrm{Na}^{+}, \mathrm{Cl}^{-}$and boron in the root growth area. Under these conditions, the environment causes nutritional imbalance and toxicity with damage to the physiological and biochemical processes by the reduction in water availability and the impairment of chlorophyll activity, photosynthetic fluorescence, production of vital reserves such as proteins, vitamins, nucleic acids with retardation or inhibition on the cellular stretching and division (MUNNS; TESTER, 2008; ARAGÃO et al., 2010; NOBRE et al., 2014; TAÏBI et al., 2016) and, with that negative effects on the growth, development and plant production.

In the soil without nitrogen, the increase in the electrical conductivity of the irrigation water up to $1.32 \mathrm{dS} \mathrm{m}^{-1}$ stimulated the leaf emission of the jackfruit seedlings to the highest value of five leaves per plant (Figure 5). On the other hand, irrigation with saline water above this value impaired the leaf emission of the seedlings with the lowest values of four leaves plant ${ }^{-1}$ on seedlings irrigated with saline water $\left(4.0 \mathrm{dS} \mathrm{m}^{-1}\right)$. In high salinity conditions, there are morphological and anatomical alterations in the plants, such as the inhibition of foliar emission, resulting in a loss of leaf area and photosynthesis and production of organic solutes as energy supply to growth, development and interaction with the environment (TAIZ et al., 2017), as observed by Oliveira et al. (2010) in sunflower plants and Nobre et al. (2013) in the initial growth of castor bean under irrigation with saline water and nitrogen fertilisation.

Data related to plants in soil with nitrogen, as a function of water salinity, did not adjust to any regression model; because of that, they were represented basically by the same average values of 4.83 and 4.85 leaves on plants treated with ammonium sulphate and urea, respectively. The absence of a significant difference between the seedlings treated with ammonium sulphate and urea is in agreement with Oliveira et al. (2010), who concluded that the interaction between saline water and nitrogen fertilisation did not have significant effects on the number of leaves emitted by sunflowers.

Figure 5. Number of leaves on jackfruit seedlings, as a function of the electric conductivity of irrigation water in soil without nitrogen $(-)$, with ammonium sulfate $(--)$ and urea $(\cdots)$.

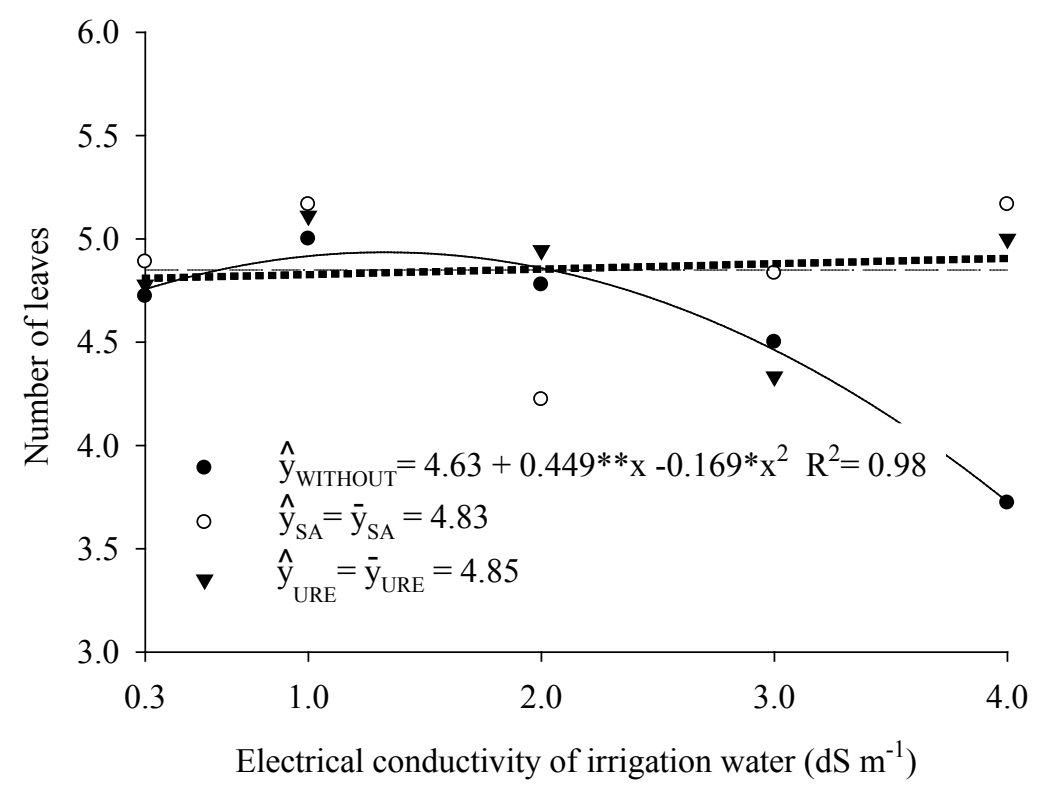


In plants irrigated with water of higher salt content $\left(4.0 \mathrm{dS} \mathrm{m}^{-1}\right)$, fertilisation with nitrogen sources provided average gains of $30 \%$ in leaf emission in relation to seedlings that did not receive fertilisation. In high salinity conditions, nitrogen can contribute to higher plant tolerance to saline stress, since the nutrient directly participates in several molecular and structural components of plants such as proline, polyamides and organic acids (TAIZ et al., 2017); they act on the osmotic regulation between a soil solution and the interior of the plant in a saline environment (AMADOR et al., 2014).

The increase in the water salinity from 0.3 to $1.74 \mathrm{dS} \mathrm{m}^{-1}$ increased the leaf area from 198.03 to $242.72 \mathrm{~cm}^{2}$, with an increase of $22.57 \%$ in the soil for plants without $\mathrm{N}$, but caused the inhibition on plants in the soil with ammonium sulphate and urea irrigated with saline water higher than $0.3 \mathrm{dS}$ $\mathrm{m}^{-1}$ (Figure 6). At the same water salinity levels of the soil without nitrogen, the values related to the seedlings in the soil with ammonium sulphate were 267.03 and $218.54 \mathrm{~cm}^{2}$, and in those treated with urea, 243.81 and $215.61 \mathrm{~cm}^{2}$; losses of 18.15 and $11.57 \%$ were expressed among the seedlings in the soil with the respective $\mathrm{N}$ sources compared to an increase of $22.5 \%$ salinity of the irrigation water in the substrate without nitrogen. The decreases are the direct response to saline indexes and an indirect response to salt sources on the osmotic pressure reduction, compared to sodium nitrate, inhibiting the water availability to seedlings (SILVA; BORGES, 2009), with negative effects on leaf expansion of the seedlings. Despite the decreases caused by both sources of $\mathrm{N}$ under saline stress conditions, the reduction in leaf area, even under nitrogen fertilisation, is considered a strategy of the plant to maintain the water potential and dilute the salts to maintain the turgescence in response to the reduction of the transpiration processes and the lower stomatal conductance (OLIVEIRA et al., 2010; ZHANG et al., 2013).

Comparatively, the data, as function of the salinity of the water and of both sources of $\mathrm{N}$, is in agreement with Nobre et al. (2010), who found that the accumulation of salts promoted by water to the soil and the nitrogen sources, which are also salts, impaired sunflower leaf growth. For these authors, the toxic effects of the mixture of salts on plants and specific ions such as $\mathrm{Na}^{+}, \mathrm{Cl}^{-}, \mathrm{SO}_{4}{ }^{2-}$ and $\mathrm{NO}_{3-}$ causes nutrient imbalance and physiological impairment to the plants (CHEN et al., 2010; DIAS; BLANCO, 2010).

Figure 6. Leaf area of jackfruit seedlings, as a function of the electric conductivity of irrigation water in soil without nitrogen (-), with ammonium sulfate (- - ) and urea $(\cdots)$.

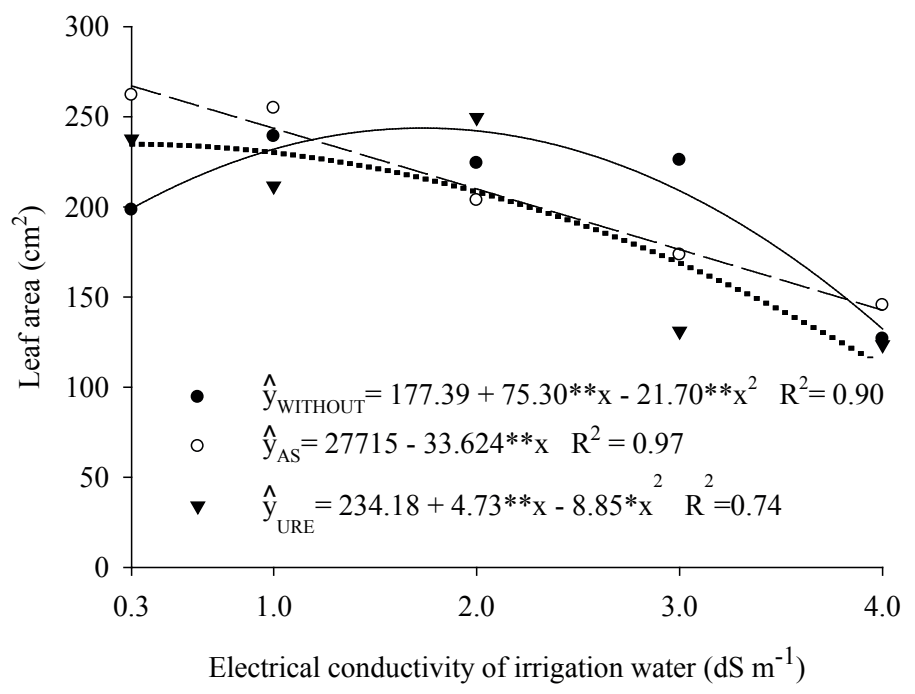


The specific leaf area of the seedlings grown on the substrate without $\mathrm{N}$ and with urea did not adjust to any mathematical model; the average values were 163.28 and $152.84 \mathrm{~cm}^{2} \mathrm{~g}^{-1}$. For the ammonium sulphate, a linear inhibition of the variable was verified at a level of $27.31 \mathrm{~cm}^{2} \mathrm{~g}^{-1}$ per unit increment of the electrical conductivity of the irrigation water, with decreases from 229.32 to $210.21 ; 182.89$; 155.58 and $128.27 \mathrm{~cm}^{2} \mathrm{~g}^{-1}$ equivalent to the average of $181.25 \mathrm{~cm}^{2} \mathrm{~g}^{-1}$ and loss of $44.07 \%$ between the seedlings irrigated with water of higher and lower levels of salinity (Figure 7). The ammonium sulphate inhibited the specific leaf area of the seedlings with an increase of saline water levels in 11.01 and $18.59 \%$ higher than to the substrates without nitrogen and fertilised with urea. The data differs from that observed by Nobre et al. (2014) who increased the specific leaf area in castor bean plants fertilised with increasing doses of nitrogen, in the form of urea and monoammonium phosphate and irrigation with saline water up to $4.4 \mathrm{dS} \mathrm{m}^{-1}$.
The increase in the concentration of salts in the irrigation water promoted a loss in the quality of the jackfruit seedlings, as evaluated by the Dickson quality index (DQI), in the substrate without nitrogen and fertilised with ammonium sulphate and urea (Figure 8). The seedlings without fertilisation and fertilised with ammonium sulphate and urea had DQI values decrease from 0.641 to $0.404 ; 0.622$ to 0.270 ; and 0.655 to 0.384 , resulting in losses of $36.97,41.37$ and $56.59 \%$ among seedlings without $\mathrm{N}$, with ammonium sulphate and urea irrigated with water of 4.0 and $0.3 \mathrm{dS} \mathrm{m}^{-1}$. According to the order of the values, the best and lowest quality seedlings were obtained in the soil without $\mathrm{N}$ and with ammonium sulphate; in spite of the declines caused by saline stress, the jackfruit seedlings had a DQI higher than 0.2 , which indicates quality for planting in the field, as concluded by Hunt et al. (1990) for forests seedlings of 'Abeto de Douglas' (Pseudotsuga menziesii), 'Pinus contarto' (Pinus contarto) and 'Pinheiro-do-Canadá' (Picea glauca).

Figure 7. Specific leaf area of jackfruit seedlings, as a function of the electric conductivity of irrigation water in soil without nitrogen $(-)$, with ammonium sulfate $(--)$ and urea $(\cdots)$.

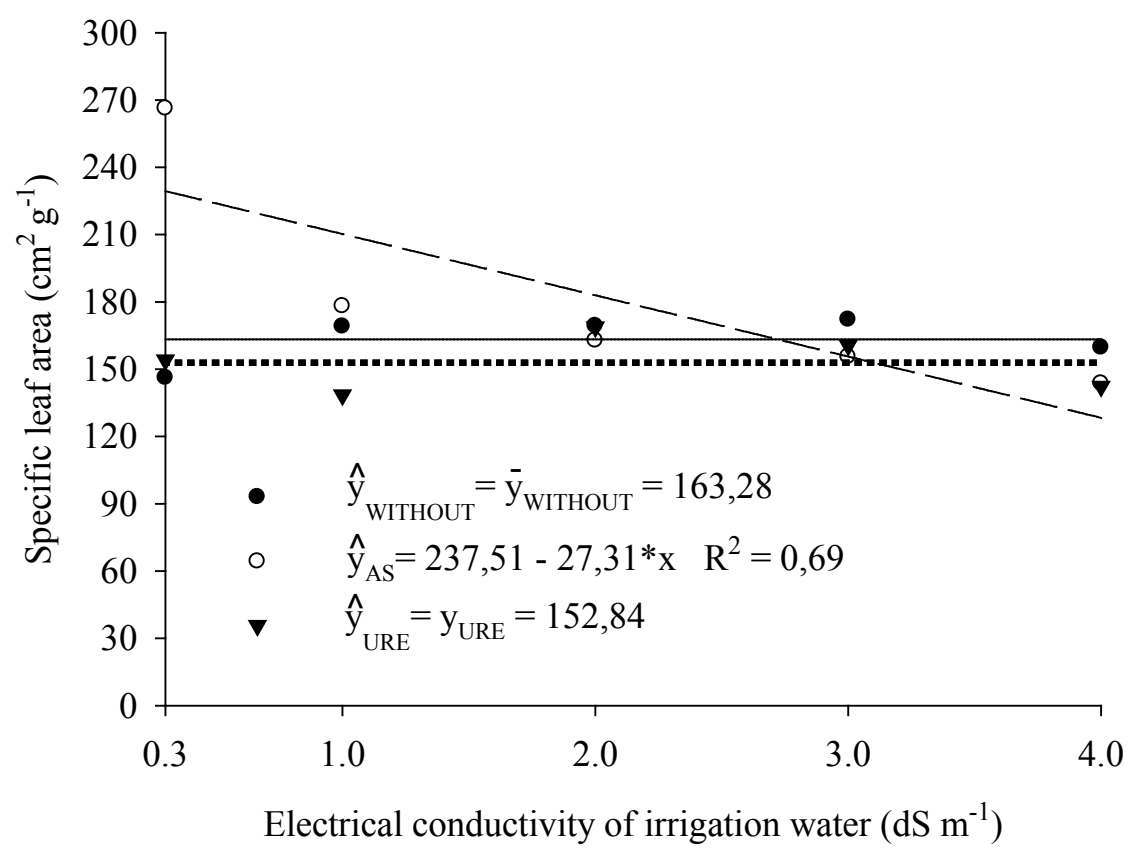

Semina: Ciências Agrárias, Londrina, v. 38, n. 4, suplemento 1, p. 2337-2350, 2017 
Figure 8. Dickson quality index of jackfruit seedlings, as a function of the electric conductivity of irrigation water in soil without nitrogen (-), with ammonium sulfate $(--)$ and urea $(\cdots)$.

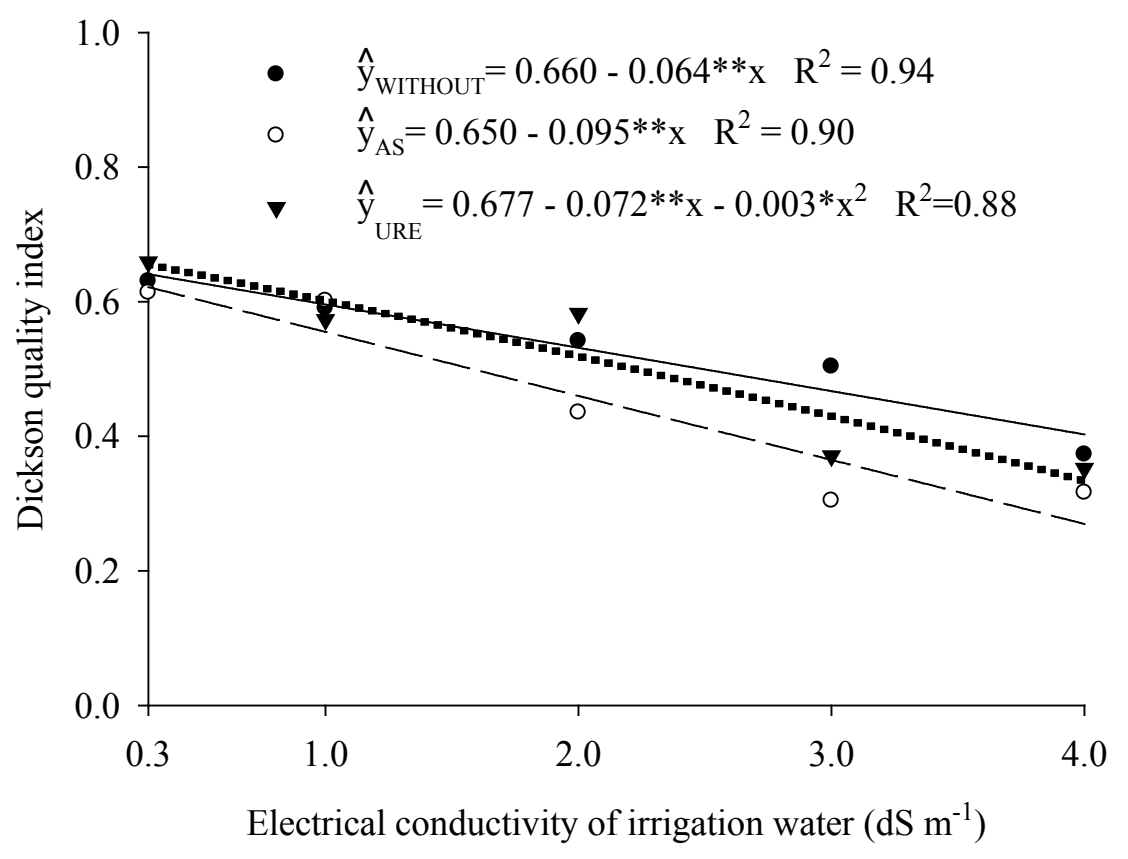

The reduction in the DQI of the seedlings irrigated with increasing salinity water is in agreement with results of Mesquita et al. (2015) for young neem plants, a forest species considered moderately tolerant to salinity in the first years of cultivation (GURUMURTHY et al., 2007). In this context, the results of the jackfruit seedlings are promising with maximum values of DQI in the seedlings irrigated with non-saline water $(0.30 \mathrm{dS}$ $\left.\mathrm{m}^{-1}\right)$ and higher salinity $\left(4.0 \mathrm{dS} \mathrm{m}^{-1}\right)$, regardless of whether the nitrogen source was applied or not.

\section{Conclusion}

An increase in the saline concentration on the water irrigation increases soil salinity, promoting growth inhibition, and also affects the quality index of the seedlings.

Ammonium sulphate is the nitrogen source that mainly contributes to an increase in soil salinity and reduces the seedling quality. In addition, it reduces the biometric growth of plants under high salinity conditions $\left(4.0 \mathrm{dS} \mathrm{m}^{-1}\right)$, with losses of $45.76 \%$ in height, $46.58 \%$ in leaf area and $44.06 \%$ in specific leaf area.

The order of the seedling quality index (DQI) values in the soil with and without each nitrogen source irrigated with non-saline water $\left(0.3 \mathrm{dS} \mathrm{m}^{-1}\right)$ was the following: ammonium sulphate $>$ urea $>$ without $\mathrm{N}$; those irrigated with higher salinity water $\left(4.0 \mathrm{dS} \mathrm{m} \mathrm{m}^{-1}\right.$ ) was: without $\mathrm{N}>$ urea $>$ ammonium sulphate.

\section{Acknowledgments}

Our thanks to the Instituto Nacional de Ciência e Tecnologia em Salinidade (INCTSal) and to the Conselho Nacional de Desenvolvimento Científico e Tecnológico (CNPq) for financial support and the granting of a scholarship to the first author. 


\section{References}

AHMED, C. B.; MAGDICH, S.; ROUINA, B. B.; BOUKHRIS, M.; ABDULLAH, F. B. Saline water irrigation effects on soil salinity distribution and some physiological responses of field grown Chemlali oliven. Journal of Environmental Management, London, v. 113, n. 1, p. 538-544, 2012.

ALVES, A. N.; GHEYI, H. R.; UYEDA, C. A.; SOARES, F. A. L.; NOBRE, R. G.; CARDOSO, J. A. F. Uso de águas salinas e adubação nitrogenada no cultivo da mamoneira BRS-Energia. Revista Brasileira de Agricultura Irrigada, Fortaleza, v. 6, n. 2, p. 151-163, 2012.

AMADOR, B. M.; MATSON, M. V. C.; ESPINOZA, J. A. V.; MONTIEL, L. G. H.; DIÉGUEZ, E. T.; HERNÁNDEZ, J. L. G. Mineral content and biochemical variables of Aloe vera L. under salt stress. Plos One, San Francisco, v. 99, n. 4, p. 1-10, 2014.

AMIRA, M. S.; QADOS, A. Effect of salt stress on plant growth and metabolism of bean plant Vicia faba (L.). Journal of the Saudi Society of Agricultural Sciences, Saudi Arabia, v. 10, n. 1, p. 7-15, 2011.

ARAGÃO, R. M.; SILVEIRA, J. A. G.; SILVA, E. N.; LOBO, A. K. M.; DUTRA, A. T. B. Absorção, fluxo no xilema e assimilação do nitrato em feijão-caupi submetido à salinidade. Revista Ciência Agronômica, Fortaleza, v. 41, n.1, p. 100-106, 2010.

ASQUIERI, E. R.; RABÊLO, A. M. S.; SILVA, A. G. M. Fermentado de jaca: estudo das características físicoquímicas e sensoriais. Ciência e Tecnologia de Alimentos, Campinas, v. 28, n. 4, p. 881-887, 2008.

ASSOULINE, S.; RUSSO, D.; SILBER, A.; OR, D. Balancing water scarcity and quality for sustainable irrigated agriculture. Water Resources Research, Washington, v. 51, n. 5, p. 3419-3436, 2015.

BENINCASA, M. M. P. Análise de crescimento de plantas: noções básicas. Jaboticabal: FUNEP, 2003. 41 p.

CAVALCANTE, L. F.; VIEIRA, M. S.; SANTOS, A. F.; OLIVEIRA, W. M.; NASCIMENTO, J. A. M. Água salina e esterco bovino líquido na formação de mudas de goiabeira cultivar Paluma. Revista Brasileira de Fruticultura, Jaboticabal, v. 32, n. 1, p. 251-261, 2010.

CHEN, W.; HOU, Z.; WU, L.; LIANG, Y.; WEI, C. Effects of salinity and nitrogen on cotton growth in arid environment. Plant and Soil, The Hague, v. 326, n. 1, p. 61-73, 2010.

DIAS, N. S.; BLANCO, F. F. Efeitos dos sais no solo e na planta. In: GHEYI, H. R.; DIAS, N. S.; LACERDA, C.
F. (Org.). Manejo da salinidade na agricultura: estudos básicos e aplicados. Fortaleza: INCTSal, 2010. p. 127141.

DICKSON, A.; LEAF, A. L.; HOSNER, J. F. Quality appraisal of white spruce and white pine seedling stock in nurseries. Forest Chronicle, Mattawa, v. 36, n. 1, p. 10-13, 1960.

EMPRESA BRASILEIRA DE PESQUISA AGROPECUÁRIA - EMBRAPA. Manual de métodos de análise do solo. Centro Nacional de Pesquisa de Solo: Rio de Janeiro, 2011, $230 \mathrm{p}$.

GARCIA, G. O.; MARTINS FILHO, S.; REIS, E. F.; MORAES, W. B.; NAZÁRIO, A. A. Alterações químicas de dois solos irrigados com água salina. Revista Ciência Agronômica, Fortaleza, v. 39, n. 1, p. 7-18, 2008.

GURUMURTHY, B. R.; NATARAJU, S. P.; RUDRAMURTHY, H. V.; SHIVANNA, M. B. Influence of soil salinity on relative biomass and critical limits of growth in selected tree species. Karnataka Journal Agricultural Science, Dharwad, v. 20, n. 1, p. 133-134, 2007.

HAN, J.; SHI, J.; ZENG, L.; XU, J.; WU, L. Effects of nitrogen fertilization on the acidity and salinity of greenhouse soils. Environmental Science and Pollution Research, Berlin, v. 22, n. 4, p. 2976-2986, 2015.

HUNT, G. A. Effect of styroblock design and cooper treatment on morfhology of conifer seedlings. In: TARGET SEEDLINGS SYPOSIUM, MEETING OF THEWESTERNFORESTNURSERYASSOCIATIONS, 1990, Roseburg. Proceedings.... Fort Collins: United States Department of Agriculture Forest Service, 1990. p. 218-222.

LORENZI, H.; BACHER, L.; LACERDA, M.; SARTORI, S. Frutas brasileiras e exóticas cultivadas: de consumo in natura. São Paulo: Instituto Plantarum de Estudos da Flora Ltda, 2006. 672 p.

MESQUITA, F. O.; NUNES, J. C.; LIMA NETO, A. J.; SOUTO, A. G. L.; BATISTA, R. O.; CAVALCANTE, L. F. C. Formação de mudas de nim sob salinidade da água, biofertilizante e drenagem do solo. Irriga, Botucatu, v. 20, n. 2, p. 193-203, 2015.

MORAIS, F. A.; GÓES, G. B.; COSTA, M. E.; VERAS, A. R. R.; CUNHA, G. O. M. Fontes e proporções de esterco na composição de substratos para produção de mudas de jaqueira. Revista Brasileira de Ciências Agrárias, Recife, v. 7, n. 4, p. 784,789, 2012.

MUNNS, R.; TESTER, M. Mechanisms of salinity tolerance. Annual Review of Plant Biology, Palo Alto, v. 1, n. 59, p. 651-81, 2008. 
NADIAN, H.; NATEGHZADEH, B.; JAFARI, S. Effects of salinity and nitrogen fertilizer on some quantity and quality parameters of sugar cane (Saccharum sp.). Journal of Food, Agriculture \& Environment, Helsinki, v. 10, n. 1, p. 470-474, 2012.

NOBRE, R. G.; GHEYI, H. R.; CORREIA, K. G.; SOARES, F. A. L.; ANDRADE, L. O. Crescimento e floração do girassol sob estresse salino e adubação nitrogenada. Revista Ciência Agronômica, Fortaleza, v. 41. n. 3, p. 358-365, 2010.

NOBRE, R. G.; LIMA, G. S.; GHEYI, H. R.; LOURENÇO, G. S.; SOARES, L. A. A. Emergência, crescimento e produção da mamoneira sob estresse salino e adubação nitrogenada. Revista Ciência Agronômica, Fortaleza, v. 44, n. 1, p. 77-85, 2013.

NOBRE, R. G.; LIMA, G. S.; GHEYI, H. R.; SOARES, L. A. A.; SILVA, A. O. Crescimento, consumo e eficiência do uso da água pela mamoneira sob estresse salino e nitrogênio. Revista Caatinga, Mossoró, v. 27, n. 2, p. 148-158, 2014.

NOVAIS, R. F.; NEVES, J. C. L.; BARROS, N. F. Ensaio em ambiente controlado. In: OLIVEIRA, A. J.; GARRIDO, W. E.; ARAÚJO, J. D.; LOURENÇO, S. (Org.). Métodos de pesquisa em fertilidade do solo. Brasília: EMBRAPA-SEA, 1991. p. 189-255.

OLIVEIRA, F. A.; MEDEIROS, J. F.; ALVES, R. C.; LINHARES, P. S. F.; MEDEIROS, A. M. A.; OLIVEIRA, M. K. T. Interação entre salinidade da água de irrigação e adubação nitrogenada na cultura da berinjela. Revista Brasileira de Engenharia Agrícola e Ambiental, Campina Grande, v. 18, n. 5, p. 480-486, 2014.

OLIVEIRA, F. A.; OLIVEIRA, F. R. A.; CAMPOS, M. S.; OLIVEIRA, M. K. T.; MEDEIROS, J. F.; SILVA, O. M. P. Interação entre salinidade e fontes de nitrogênio no desenvolvimento inicial da cultura do girassol. Revista Brasileira de Ciências Agrárias, Recife, v. 5, n. 4, p. 479484, 2010.
RICHARDS, L. A. Diagnosis and improvement of saline and alkaline soils. Washington: United States Salinity Laboratory Staff, 1954. 160 p.

SHAHID, S. A.; RAHMAN, K. Soil salinity development, classification, assessment, and management in irrigated agriculture. In: PESSARAKLI, M. (Org.). Handbook of plant and crop stress. Boca Raton: CRC Press Taylor \& Francis Group, 2011. p. 24-39.

SILVA, D. J.; BORGES, A. L. Fertilizante para irrigação. In: BORGES, A. L.; COELHO, E. F. (Org.). Fertirrigação em fruteiras tropicais. Cruz das Almas: Embrapa Mandioca e Fruticultura Tropical, 2009. p. 2036.

STATISTICAL ANALYSIS SYSTEM INSTITUTE SAS Institute Inc. SAS/STAT ${ }^{\circledR} 9.2$ User's Guide. Cary: SAS Institute Inc, 2008. 16 p.

TAÏBI, K.; TAÏBI, F.; ABDERRAHIM, L.A.; ENNAJAH, A.; BELKHODJA, M.; MULET, J. M. Effect of salt stress on growth, chlorophyll content, lipid peroxidation and antioxidant defense systems in Phaseolus vulgaris $\mathrm{L}$. South African Journal of Botany, Pretoria, v. 105, n. 1, p. 306-312, 2016.

TAIZ, L.; ZEIGER, E.; MØLLER, I. M.; MURPHY, A. Fisiologia e desenvolvimento vegetal. 6. ed. Porto Alegre: Artmed, 2017. 858 p.

ZHANG, L.; ZHANG, G.; WANG, Y.; ZHOU, Z.; MENG, Y.; CHEN, B. Effect of soil salinity on physiological characteristics of functional leaves of cotton plants. Journal of Plant Research, Tokyo, v. 126, n. 2, p. 293-304, 2013. 